\title{
Comparison between infrared and hot-blade beak trimming methods in white and brown pullets: performance, organ and bone development
}

\author{
[Comparativo entre debicagem infravermelha e por lâmina-quente em linhagens de frangas leves \\ e semi-pesadas: desempenho, desenvolvimento ósseo e de órgãos] \\ P.C. Guarnieri ${ }^{1}$, H. Pagnussatt ${ }^{1}$, E. Aniecevski ${ }^{2}$, A. Dal Santo ${ }^{2}$, F. Leite ${ }^{2}$, \\ F.D.A. Valentini ${ }^{2}$, C.S. Facchi ${ }^{1}$, G. Zaccaron ${ }^{2}$, G.E. Bosetti ${ }^{1}$, G. Rossatto ${ }^{2}$, \\ M.M. Boiago ${ }^{3}$, F.C. Tavernari ${ }^{4}$, S.M.B. Artoni ${ }^{5}$, T.G. Petrolli ${ }^{6^{*}}$ \\ ${ }^{1}$ Aluno de pós-graduação - Universidade do Oeste de Santa Catarina - Xanxerê, SC \\ ${ }^{2}$ Aluno de graduação - Universidade do Oeste de Santa Catarina - Xanxerê, SC \\ ${ }^{3}$ Universidade do Estado de Santa Catarina - Chapecó, SC \\ ${ }^{4}$ Empresa Brasileira de Pesquisa Agropecuária - Concórdia, SC \\ ${ }^{5}$ Universidade Estadual Paulista Júlio de Mesquita Filho - Jaboticabal, SP \\ ${ }^{6}$ Universidade do Oeste de Santa Catarina - Xanxerê, SC
}

\begin{abstract}
The purpose of this study was to evaluate infrared beak trimming versus hot-blade beak trimming on performance, organ and bone development of laying pullets, using 240 birds, at 0-16 weeks of age, from two strains (white layer - Hy-Line W36 and brown layer - Hy-Line Brown). Infrared debeaking was performed on the first day of life in the hatchery, whereas hot-blade beak trimming was performed at eight days of age. Zootechnical performance at 6, 9, 12 and 15 weeks of age was analyzed. At the end of the trial, one Bird per experimental unit was euthanized for liver, gizzard, proventriculus, heart and small intestine relative weight evaluation. Both tibiotarsus were collected to measure bone breaking resistance, bone mineral content and bone densitometry. There was higher body weight and feed intake in both bird strains submitted to infrared beak trimming. Additionally, hot-blade white layers presented lower body development and feed intake. The debeaking methods did not influence relative organ weights or tibiotarsus parameters evaluated. We conclude that the infrared beak trimming method promotes better pullet body development than the conventional hot-blade method, improving feed intake, without compromising organ and bone development, being a more adequate debeaking method to be used in layer production.
\end{abstract}

Keywords: animal welfare, debeaking, densitometry, layer hens, poultry

\section{RESUMO}

Para avaliar a debicagem infravermelha versus a debicagem pelo método da lâmina quente no desempenho, no desenvolvimento de órgãos e na qualidade óssea de poedeiras em recria, foram utilizadas 240 aves, entre zero e 16 semanas de idade, em duas linhagens (branca - Hy-Line W36 e vermelha - Hy-Line Brown). A debicagem por infravermelho foi realizada no primeiro dia de vida no incubatório, enquanto a debicagem com lâmina quente foi realizada aos oito dias de idade. Analisou-se o desempenho zootécnico na sexta, nona, $12^{a}$ e $15^{a}$ semanas de idade. No final do estudo, uma ave por unidade experimental foi eutanasiada para avaliação do peso relativo do fígado, da moela, do proventrículo, do coração e do intestino delgado, e ossos do tibiotarso foram coletados para avaliação da resistência à ruptura, do conteúdo mineral e da densitometria óssea. Houve maior peso corporal e consumo alimentar nas aves pertencentes às duas linhagens quando submetidas à debicagem por infravermelho, sem haver influência sobre o peso relativo dos órgãos e a qualidade óssea. Conclui-se que o método de debicagem por radiação infravermelha promove melhor desenvolvimento corporal das frangas em relação à debicagem por lâmina quente, melhorando consumo de ração, sem comprometer o desenvolvimento de órgãos e ossos, sendo mais adequada para utilização na avicultura de postura comercial.

Palavras-chave: avicultura, bem-estar animal, debicagem, densitometria, poedeiras comerciais

Recebido em 9 de março de 2020

Aceito em 9 de junho de 2020

*Autor para correspondência (corresponding author)

E-mail: tiago.petrolli@unoesc.edu.br 


\section{INTRODUCTION}

Substantial consumer pressure demonstrates that some practices adopted by the poultry industry should be revised as soon as possible, particularly those related to the management of debeaking methods. Pecking committed by dominant bird causes prolonged stress, decreased feed intake and worsening feed conversion, and may even affect internal and external egg quality (Vieira Filho, et al., 2016). Also, whole beak pullets waste and select feed grains, compromising flock performance and, in more severe cases, mortality by cannibalism (Yamauchi et al., 2017).

Beak trimming is widely practiced in the poultry industry (Gonçalves et al., 2010; Oka et al., 2017), usually twice, with the first one being done between eight and 10 days of life, and the second one between eight and 10 weeks of age. Generally, the first debeaking is deeper, in a 2$4 \mathrm{~mm}$ spacing between the cut and the bird's nostrils, and the second cut is generally is $5-8 \mathrm{~mm}$ spaced. Hot blade debeaking is performed at 700 to $800^{\circ} \mathrm{C}$, being described as a practice to reduce feather pecking and cannibalism, and if done in an adequate way, it reduces feed waste and mortality, as well as improving feed conversion (Laganá et al., 2011; Struthers et al., 2019).

However, hot-blade (conventional) method is a very invasive method, which causes a high rate of pain in birds, and there is a worldwide tendency for the abolition of this practice. Additionally, the hot-blade debeaking method is totally dependent on human labor, and errors and lack of uniformity in the beak-trimming process can occur with great frequency. There are alternatives to conventional debeaking, and infrared beak-trimming is the most promising, being used in day-old chicks, exposing the bird beak to an infrared radiation, in an automatized machine.

Ten days after the procedure the tip of the beak gradually drops, causing less pain in birds. Additionally, the technique does not depend on human labor and promotes a longer beak, which facilitates pullet's voluntary intake, and could improve bird development. The aim of this study was to evaluate two methods of beak trimming, in white and brown layer pullets, on laying performance, organ and bone development during the rearing phase.

\section{MATERIAL AND METHODS}

Research on animals was conducted according to the institutional ethics committee on animal use (Ceua/UnoescProtocol number 66/2018). Birds received unlimited access to feed and water. The experiment was carried out in Xanxerê, Santa Catarina, Brazil (latitude 26 52'37 "south, longitude 52 $24^{\prime} 15^{\prime \prime}$ west and elevation of 800 meters), using a total of 240 birds, from 0 to 16 weeks of age. Two debeaking methods (hot blade and infrared radiation) were evaluated in two strains (white layer - Hy-Line W36 and brown layer Hy-Line Brown), as demonstrated in Figure 1. The birds were allocated on the first day of life in a completely randomized design with $2 \times 2$ factorial arrangement, consisting of four treatments with six replications each, comprising of 10 birds in each experimental unit, in a 10 pullets $/ \mathrm{m}^{2}$ housing density.

Laser debeaking was performed in the hatchery on the first day of life, using Nova-Tech Poultry Service Processor (PSP) (Nova-Tech, Willmar, $\mathrm{MN}$, USA), an equipment that emits infrared energy on the tip of the beak, causing tissue death and subsequent separation of this portion on the second week of life. The equipment was supplied by $2723^{-1} \mathrm{~mm}$ interface plates, in length and height., and the infrared light intensity used was $46 \mathrm{~nm}$, maintaining $2 \mathrm{~mm}$ of the beak length. Pullets subjected to conventional debeaking underwent the procedure at eight days of life, using a conventional hot-blade debeaker (Lyon, Chula Vista, CA, USA), with a temperature of $700^{\circ} \mathrm{C}$, for cutting and immediate cauterization of the beak, cutting the final third of the beak, measured at $2 \mathrm{~mm}$ from the birds nostrils.

Diets were formulated to meet poultry requirements in the rearing phases, according to each strain manual for all nutrients (W-36..., 2016 and Brown..., 2018), and feed and water were provided freely throughout the experimental period. Birds were housed in $2 \mathrm{~m}^{2}$ boxes on wood shavings, being weighed at the beginning of the experiment, and later on the sixth, ninth, twelfth and sixteenth week of age, together with the feed leftovers, to determine live weight, weight gain, feed intake and feed conversion. For digestive organ yield analysis, on the last day of the experiment, one bird was slaughtered per experimental unit, choosing a pullet with the closest body weight to the average weight of the 


\section{Comparison between...}

pen, and liver, gizzard, proventriculus, heart and small intestine were weighted to obtain absolute organ weights.

For bone analysis, both tibiotarsus bones were collected, subsequently frozen and then submitted to bone rupture resistance and bone quality parameters analysis. For bone breaking strength, right tibiotarsus were subjected to a texturometer (TA.XT plus C, Extralab, Itatiba, SP, Brazil) that measures the units of kilogram force (kgf) necessary to break the bone. The equipment was calibrated to allow the diaphysis length of $6 \mathrm{~cm}$ for all bone samples, as this distance was sufficient to ensure that all bones were placed on their diaphysis. The load was then applied at the bone's geometric mean point between the 2 supports, and all the measurements were taken by the same operator.

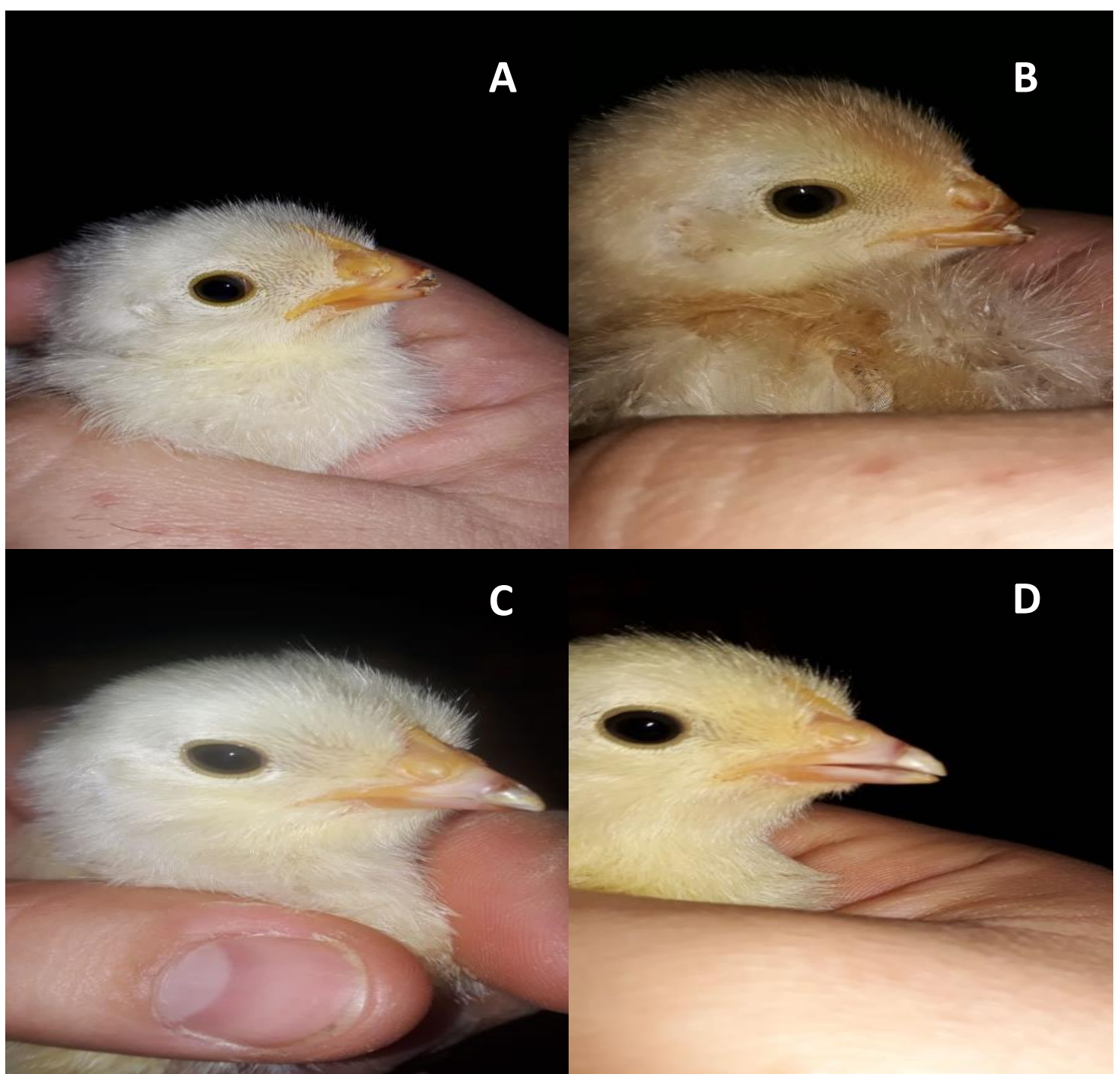

Figure 1. Beak-trimmed layer pullets at 12 days old. A - Hot-blade white layer; B - Hot-blade brown layer; C - Infrared white-layer; D - Infrared brown layer.

Bone quality, bone mineral density (BMD) $\left(\mathrm{g} / \mathrm{cm}^{2}\right)$, bone mineral content $(\mathrm{BMC})(\mathrm{g})$ and surface area $\left(\mathrm{cm}^{2}\right)$ were analyzed, using left tibiotarsus, in the dorsoventral position, using a dual energy X-ray absorptiometer (DXA) (Horizon Discovery Dxa, Hologic, Marlborough, MA, USA), evaluating the entire bone. Prior to sampling, the device was calibrated with bone and 


\section{Guarnieri et al.}

tissue equivalents supplied by the manufacturer (Hologic $®)$. Experimental data were subjected to analysis of variance and, in cases of significant difference, means were subjected to the Tukey test, considering a 0.05 significance level, using SAS University software.

\section{RESULTS}

Differences were observed on feed intake of birds, where pullet beaks trimmed by infrared radiation had higher feed intake $(\mathrm{P}<0,01)$ than those debeaked using the hot blade method (Table 1). This improvement was observed both in white and brown strains. Also, bird weight difference was found at six, nine ant fifteen weeks of age, where birds debeaked with infrared were heavier $(\mathrm{P}<0.01)$ than pullets submitted hot blade debeaking. At six weeks-old, hot-blade white layers beak-trimmed showed worst body weight and weight gain $(\mathrm{P}<0.01)$. Infrared debeaked pullets weight gain in were greater $(\mathrm{P}<0.05)$ than birds debeaked using the hot-blade method, and additionally, white strain chicks had lower weight gain $(\mathrm{P}<0.01)$ than brown line birds. Also, whitelaying birds had higher feed conversion $(\mathrm{P}<0.001)$ than the brown laying birds.

Table 1. Laying performance in the rearing phase

\begin{tabular}{|c|c|c|c|c|}
\hline 6 weeks & Weight $(\mathrm{g})$ & Weight gain $(\mathrm{g})$ & Feed Intake $(\mathrm{g})$ & Feed conversion \\
\hline White-layer - Laser & $487.50 \mathrm{Bb}$ & $452.00 \mathrm{Bb}$ & $1.43 \mathrm{Aa}$ & $3.17 \mathrm{Ba}$ \\
\hline White-layer - Hot blade & $442.50 \mathrm{Bc}$ & $405.20 \mathrm{Bc}$ & $1.33 \mathrm{Ab}$ & $3.28 \mathrm{Ba}$ \\
\hline Brown layer - Laser & $547.50 \mathrm{Aa}$ & $512.50 \mathrm{Aa}$ & 1.39Aa & 2.72Aa \\
\hline Brown layer - Hot blade & $492.50 \mathrm{Ab}$ & $456.50 \mathrm{Ab}$ & $1.28 \mathrm{Ab}$ & $2.82 \mathrm{Aa}$ \\
\hline $\mathrm{CV}(\%)$ & 3.37 & 3.62 & 5.55 & 3.84 \\
\hline P Value - Strain & $<0.001$ & $<0.001$ & 0.282 & $<0.001$ \\
\hline P Value - Debeaking & $<0.001$ & $<0.001$ & 0.018 & 0.089 \\
\hline P Value - Debeaking x Strain & 0.557 & 0.586 & 0.080 & 0.949 \\
\hline 9 weeks & Weight $(\mathrm{g})$ & Weight gain $(\mathrm{g})$ & Feed Intake $(\mathrm{g})$ & Feed conversion \\
\hline White-layer-Laser & $673.80 \mathrm{Bb}$ & 202.40 & $660.40 \mathrm{Bb}$ & 3.45 \\
\hline White-layer- Hot blade & $565.93 \mathrm{Cc}$ & 239.80 & $552.74 \mathrm{Cc}$ & 2.87 \\
\hline Brown layer - Laser & 816.20Aa & 247.40 & 768.00Aa & 3.11 \\
\hline Brown layer - Hot blade & $756.20 \mathrm{Ab}$ & 229.60 & $692.60 \mathrm{Ab}$ & 3.01 \\
\hline $\mathrm{CV}(\%)$ & 3.34 & 14.98 & 3.02 & 12.64 \\
\hline P-Value Strain & $<0.001$ & 0.275 & $<0.001$ & 0.574 \\
\hline P-Value Debeaking & 0.002 & 0.533 & $<0.001$ & 0.072 \\
\hline P-Value Strain x Debeaking & 0.105 & 0.092 & 0.029 & 0.189 \\
\hline 12 weeks & Weight $(\mathrm{g})$ & Weight gain $(\mathrm{g})$ & Feed Intake (g) & Feed conversion \\
\hline White-layer-Laser & $995.00 \mathrm{Ba}$ & $501.00 \mathrm{Ba}$ & $1600.00 \mathrm{Ba}$ & $3.19 \mathrm{Ab}$ \\
\hline White-layer- Hot blade & $955.00 \mathrm{Ba}$ & $521.00 \mathrm{Ba}$ & $1370.00 \mathrm{Bb}$ & $2.65 \mathrm{Aa}$ \\
\hline Brown layer - Laser & $1180.00 \mathrm{Aa}$ & 611.00Aa & 1710.00Aa & $2.92 \mathrm{Ab}$ \\
\hline Brown layer - Hot blade & $1112.00 \mathrm{Aa}$ & 580.00Aa & $1540.00 \mathrm{Ab}$ & $2.63 \mathrm{Aa}$ \\
\hline CV (\%) & 6.09 & 13.35 & 7.55 & 14.35 \\
\hline Strain & $<0.001$ & 0.018 & 0.015 & 0.425 \\
\hline Debeaking & 0.080 & 0.943 & 0.001 & 0.039 \\
\hline Strain x Debeaking & 0.635 & 0.508 & 0.580 & 0.495 \\
\hline 15 weeks & Weight $(\mathrm{g})$ & Weight gain $(\mathrm{g})$ & Feed Intake $(\mathrm{g})$ & Feed conversion \\
\hline White-layer-Laser & $1150.00 \mathrm{Bb}$ & $650.00 \mathrm{Ba}$ & $2720.00 \mathrm{Ba}$ & $4.14 \mathrm{Bb}$ \\
\hline White-layer- Hot blade & $1130.00 \mathrm{Bc}$ & $690.00 \mathrm{Ba}$ & $2530.00 \mathrm{Bb}$ & $3.66 \mathrm{Ba}$ \\
\hline Brown layer - Laser & $1390.00 \mathrm{Aa}$ & 820.00Aa & 3040.00Aa & $3.7 \mathrm{Ab}$ \\
\hline Brown layer - Hot blade & $1300.00 \mathrm{Ab}$ & 770.00Aa & $2750.00 \mathrm{Ab}$ & $3.54 \mathrm{Aa}$ \\
\hline CV $(\%)$ & 3.14 & 6.50 & 5.56 & 6.49 \\
\hline P-Value Strain & $<0.001$ & $<0.001$ & 0.001 & 0.021 \\
\hline P-Value Debeaking & 0.006 & 0.783 & 0.003 & 0.010 \\
\hline P-Value Strain x Debeaking & 0.078 & 0.068 & 0.504 & 0.162 \\
\hline
\end{tabular}

*Different capital letters in the same column indicate strain evaluation. Different lowercase letters in the same column indicate debeaking methods. 
There was greater feed intake (Table 1) at 9,12 and 15 weeks $(\mathrm{P}<0.05)$ by birds subjected to laser debeaking. In the nine week-old evaluation, the hot-blade white layer group had the lowest weight and feed intake $(\mathrm{P}<0.01)$, showing that the hotblade debeaking method is the most compromising for white-layers. In addition, white-laying birds had lower weights $(\mathrm{P}<0.05)$ than brown laying birds. On the $9^{\text {th }}$ and $15^{\text {th }}$ week of age, infrared debeaked pullets were heavier $(\mathrm{P}<0.05)$ than the hot-blade debeaked pullets. Birds belonging to the white-laying strain had lower weights $(\mathrm{P}<0.05)$ than brown laying birds.

Feed conversion ratio was lower $(\mathrm{P}<0.05)$ in birds at 12 and 15 weeks subjected to hot blade debeaking when compared with birds subjected to the infrared method; however, on the ninth week of age, there was no difference $(\mathrm{P}>0.05)$ between chicks subjected to both methods. The birds in the $15^{\text {th }}$ week white-laying strain had higher $(\mathrm{P}<0.05)$ feed conversion than the brown layers, a situation not observed on the $9^{\text {th }}$ or $12^{\text {th }}$ weeks $(\mathrm{P}>0.05)$. Additionally, at 15 weeks, hot-blade beak trimmed white layers had the lowest body weight $(\mathrm{P}<0.05)$.

There was no difference $(\mathrm{P}>0.05)$ in liver, gizzard or heart weight between pullets from both debeaking groups. However, there was higher proventriculus weight $(\mathrm{P}<0.05)$ in brown layer birds subjected to laser debeaking than in brown layers debeaked using the hot blade method and white-layer birds, in both beak trimming methods. Differences were observed in liver, gizzard, proventriculus and heart due to strain, which were heavier $(\mathrm{P}<0.05)$ in brown-laying birds. There was no difference $(\mathrm{P}>0.05)$ in small intestine weights between debeaking or strain groups. (Table 2).

Table 2. Organ evaluation at 15 weeks of age

\begin{tabular}{lccccc}
\hline Liver $(\mathrm{g})$ & $\begin{array}{c}\text { Gizzard } \\
(\mathrm{g})\end{array}$ & $\begin{array}{c}\text { Proventriculus } \\
(\mathrm{g})\end{array}$ & $\begin{array}{c}\text { Heart } \\
(\mathrm{g})\end{array}$ & Small intestine $(\mathrm{g})$ \\
\hline White-layer- Laser & $23.00 \mathrm{Ba}$ & $40.60 \mathrm{Ba}$ & $6.00 \mathrm{Bb}$ & $5.00 \mathrm{Ba}$ & 42.20 \\
White-layer-Hot blade & $21.80 \mathrm{Ba}$ & $34.40 \mathrm{Ba}$ & $5.00 \mathrm{Cc}$ & $4.80 \mathrm{Ba}$ & 44.00 \\
Brown layer - Laser & $26.00 \mathrm{Aa}$ & $45.20 \mathrm{Aa}$ & $7.00 \mathrm{Aa}$ & $7.00 \mathrm{Aa}$ & 51.20 \\
Brown layer - Hot blade & $25.20 \mathrm{Aa}$ & $40.80 \mathrm{Aa}$ & $6.00 \mathrm{Bb}$ & $6.40 \mathrm{Aa}$ & 48.80 \\
\hline CV $(\%)$ & 11.86 & 14.19 & 14.43 & 12.19 & 13.46 \\
P-Value Strain & 0.023 & 0.046 & 0.020 & $<0.001$ & 0.153 \\
P-Value Debeaking & 0.443 & 0.054 & 0.020 & 0.224 & 0.320 \\
P-Value Strain x Debeaking & 0.877 & 0.729 & 1.000 & 0.536 & 0.487 \\
\hline
\end{tabular}

*Different capital letters in the same column indicate strain evaluation. Different lowercase letters in the same column indicate debeaking methods.

Bone resistance did not differ (Table 3) in birds in either debeaking groups. However, there was higher bone strength $(\mathrm{P}=0.037)$ in brown layers than in white layers. No alterations were found in bone mineral content at 15 weeks-old $(\mathrm{P}>0.05)$ between debeaking groups. White-laying birds had lower bone mineral content $(\mathrm{P}<0.05)$ than brown laying birds. There were no differences
$(\mathrm{P}>0.05)$ between debeaking groups or strains on bone surface area. Similarly, on the $15^{\text {th }}$ week there were no differences $(\mathrm{P}>0.05)$ between debeaking groups in terms of bone mineral density, however, brown layers had higher bone mineral density $(\mathrm{P}<0.05)$ than did white-laying birds.

Table 3. Bone parameter evaluation of layers at 15 weeks of age

\begin{tabular}{lcccc}
\hline & $\begin{array}{c}\text { Bone breaking } \\
\text { strength }(\mathrm{kgf})\end{array}$ & $\begin{array}{c}\text { Bone mineral } \\
\text { content }(\mathrm{g})\end{array}$ & $\begin{array}{c}\text { Surface area } \\
\left(\mathrm{cm}^{2}\right)\end{array}$ & $\begin{array}{c}\text { Bone mineral } \\
\text { density }\left(\mathrm{g} / \mathrm{cm}^{2}\right)\end{array}$ \\
\hline White-layer- Laser & $13.32 \mathrm{Ba}$ & $0.45 \mathrm{Ba}$ & 4.06 & $0.11 \mathrm{Ba}$ \\
White-layer- Hot blade & $12.40 \mathrm{Ba}$ & $0.38 \mathrm{Ba}$ & 3.40 & $0.11 \mathrm{Ba}$ \\
Brown layer - Laser & $14.27 \mathrm{Aa}$ & $0.65 \mathrm{Aa}$ & 4.39 & $0.15 \mathrm{Aa}$ \\
Brown layer - Hot blade & $15.01 \mathrm{Aa}$ & $0.59 \mathrm{Aa}$ & 4.13 & $0.14 \mathrm{Aa}$ \\
\hline CV $(\%)$ & 12.71 & 25.54 & 16.94 & 19.34 \\
P-Value Strain & 0.037 & 0.003 & 0.097 & 0.007 \\
P-Value Debeaking & 0.910 & 0.267 & 0.150 & 0.639 \\
P-Value Strain x Debeaking & 0.308 & 0.894 & 0.518 & 0.639 \\
\hline
\end{tabular}

*Different capital letters in the same column indicate strain evaluation. Different lowercase letters in the same column indicate debeaking methods. 


\section{DISCUSSION}

Infrared debeaked birds had higher final weights and weight gain due to the reduced invasiveness and better pullet recovery after the procedure, resulting in better bird beak uniformity and less callus formation. Vieira Filho et al. (2016) obtained similar results when evaluating infrared and conventional debeaking, describing higher weights in infrared beak trimmed birds. Oka et al. (2017) compared infrared and conventional methods and found better body development in infrared radiation debeaked birds. Dennis and Cheng (2010) investigated the characteristics related to production and stress in birds subjected to both beak trimming methods and noted infrared debeaking consists in a more welfare-friendly method, directly or indirectly improving body development and production.

Callus in beaks can cause pain, resulting in lower feed intake in the next days following the procedure, something more often seen in birds subjected to the hot blade method. White-laying birds had lower weights and weight gains than did brown laying birds due to genetic characteristics; the white-layers have smaller body structures than brown layers, as indicated by the performance standards in the Hy-line strains management guide.

Laser debeaked birds had higher body weight and consumed more feed than the hot blade debeaked birds, because laser debeaking methods are less harmful to bird's beak structure, resulting in gradual separation and better uniformity, reducing the recovery time required. Such findings are similar to the conclusions described by Vieira Filho et al. (2016), who observed that birds subjected to infrared radiation had higher feed intake than did layers subjected to the conventional method. Oka (2017) explains feed intake is governed by the hypothalamus, and during debeaking, changes in apprehension receptors found in the bird's beak may cause changes in homeostatic balance, causing sensory, motor, emotional and autonomic dysfunctions.

The absence of differences in feed intake between strains, suggests there is no distinction in this behavior during the early phase of pullets' development. Debeaking reduces feed intake (Marchant-Forde and Cheng, 2010), however, the infrared debeaking method has less effect on ingestion than the conventional hot blade method, probably related to other advantages of the infrared method, like the absence of open wounds and potential sites of bleeding and infection and better beak adaptation to feed intake after the procedure, due to gradual change in beak length.

The hot blade-debeaking method promotes lower feed conversion rates regarding more feed intake from infrared-debeaked birds. This result was also described by Marchant-Forde and Cheng (2010), who found lower feed intake in birds exposed to the hot blade method than those exposed to infrared radiation. According to Struthers et al. (2019), a possible explanation as to why birds subjected to the laser method consume more ration than those subjected to the hot blade is the shorter recovery time after beak treatment and better uniformity of the beak, resulting in easier feed capture by beak.

White-laying breeders had lower weight, weight gain and feed intake than did brown laying birds, due to their smaller constitution. A similar result was found by Rodrigueiro et al. (2007) when evaluating feed intake of two Hy-line (white and brown) laying strains. The authors noted brown laying females consumed $4.91 \%$ more feed than did white-laying birds. There was no difference in feed conversion of layers between the different strains, whose two genetics were similar. Organ weights were similar in both debeaking groups. Santos et al. (2012) reported small intestine increases of about $600 \%$ within the first seven days of life with the infrared debeaking method on the first day of life, one week before the hot-blade method was used. It may be the case that if the hot blade method were also performed on the first day, we would have different results in terms of sizes of the digestive organs.

The hearts, livers, gizzards and proventriculus of brown layers were heavier because they have larger body structures, and consequently some organs tend to be larger because their development is proportional to total body size. Differences in the development of digestive tract organs between white and brown layers are caused by physiological changes in the birds, due to the genetic improvement programs of each strain (Braz et al., 2011; Freitas et al., 2014). Furthermore, feed intake was higher than that of white-laying birds, following the expected results of feed intake and body weight in the two Hy-line 
management guides (2016) strains. In addition, white-laying hens are selected for lower body weight, maturity and thus less feed intake, and it interferes in organ digestive system growth, being lower when compared to brown layers organs. The exception was found in proventriculus evaluation, due to the smaller weight found in hotblade trimmed white layers. As this strain naturally presents a small size, the feed intake reduction observed causes lower proventriculus development, due to less digestive requirement.

By contrast, there were no differences in the small intestine size between strains, possibly due to the better efficiency of the gizzard and proventriculus to digest feed, which was greater than that of white-laying birds. Bone development did not differ between debeaking groups. Shorter recovery time and less possible influence on feed acquisition should correlate with shorter stress time, and it should be noted that bone evaluations were performed at week 15 , and debeaking occurred in the first and second week, possibly providing sufficient time for bone development. Kang et al. (2016), when evaluating bone mineral content in layers in different population density increases, noted that tibiotarsus bone mineral density was lower with stocking density of 10 birds $/ \mathrm{m}^{2}$, compared with the densities of 6.7 or 8 birds $/ \mathrm{m}^{2}$. When evaluating the eggshell strength produced by these breeders, they noticed females at higher density obtained worse results, suggesting an effect of well-being on bone development and production.

Birds in the infrared debeaking group had higher feed intake than birds in hot blade group, influencing the amount of calcium ingested and absorbed, thereby affecting bone mineral density, as cited by Kang et al. (2016) when assessing population density and feed intake against bone mineral content, and Schreiweis et al. (2003) evaluating various dietary calcium levels and the effect on bone mineral density and bone mineral content. In the present research, were found no influence of both beak trimming methods on all bone parameters evaluated, demonstrating that infrared and hot-blade methods could be used without compromising bone quality. White-laying birds had lower bone breaking strength, bone mineral content and lower bone mineral density than brown layers, because of genetic characteristics manifesting as different body structures, resulting in different sizes and bone compositions. Fernandes (2012) commented that bone tissue is closely related to animal growth, because it undergoes constant changes in its constitution.

Therefore, content and resistance would certainly be different between the two strains. Bone quality is an important parameter to be monitored in layer hens, due to the subsequent productive cycle, where major bone problems can occur in birds, especially those raised in cage systems. In addition, as bones comprise the main mineral reserves in the body for the formation of eggshells, the rearing system must allow birds to have no problems in bone development during the rearing phase.

Layer hens should have adequate bone development prior to laying (Cruz et al., 2012), and, as skeletal problems in layer chickens are gaining attention due to animal welfare and economic losses in the egg industry (Guo et al., 2017), bone monitoring and evaluation is a very important practice, and bone breaking strength and BMD are two important parameters to assess the bone quality in birds. Without sufficient skeletal integrity, layers succumb to leg problems including tibial dyschondroplasia, twisted leg, rickets, kinky back, brittle bone disease, and general lameness (Lilburn, 1994; Zhou et al., 2007). Additionally, the significance that bone plays as a reservoir for minerals deposited in the shell is important, and the possibility of osteoporosis occurrence can contribute to significant economic losses in the egg industry.

\section{CONCLUSIONS}

The infrared debeaking method promotes better body development and higher feed intake during the rearing pullet phase, in both evaluated strains, ensuring adequate bone and organ development. It may be an adequate substitute for the conventional debeaking method. As expected, the brown-layer strain has higher body development and feed intake than the white-layer strain.

\section{REFERENCES}

BRAZ, N.M.; FREITAS, E.R.; BEZERRA, R.M.; CRUZ, C.E.B. et al. Fibra na ração de crescimento e seus efeitos no desempenho de poedeiras nas fases de crescimento e postura. Rev. Bras. Zootec., v.40, p.27442753, 2011. 


\section{Guarnieri et al.}

BROWN commercial layers management guide. Des Moines, IA, USA: Hy-Line, 2018. p.1-32.

CRUZ, C.EB.; FREITAS, E.R.; FARIAS, N.N.P. et al. Bone quality of laying hens fed different levels of fiber in the growth phase (7 to 17 weeks of age). Rev. Bras. Zootec., v.41, p.2032-2038, 2012.

DENNIS, R.L.; CHENG, H.W. A comparison of infrared and hot blade beak trimming in laying hens. Poult. Sci., v.9, p.716-719, 2010.

FERNANDES, M.N.S. Principais problemas locomotores na avicultura industrial. PUBVET, v.6, p.18, 2012.

FREITAS, E.R.; BRAZ, N.M.; WATANABE, P.H. et $a l$., Fiber level for laying hens during the growing phase. Ciênc. Agrotecnol., v.38, p.188-198, 2014.

GONÇALVES, F.M.; GENTILINI, F.P.; ANCIUTI, M.A. et al. Administração de antibiótico em poedeiras semipesadas durante o processo de debicagem. Arch. Zootec., v.59, p.226, 2010.

GUO, J.; SUN, C.; QU, L.; SHEN, M.; DOU, T. et al. Genetic architecture of bone quality variation in layer chickens revealed by a genome-wide association study. Sci Rep., v.7, p.45317, 2017.

KANG, H.K.; PARK, S.B.; KIM, S.H.; KIM, C.H. Effects of stock density on the laying performance, blood parameter, corticosterone, litter quality, gas emission and bone mineral density of laying hens in floor pens. Poult. Sci., v.95, p.2764-2770, 2016.

LAGANÁ, C.; PIZZOLANTE, C.C.; TOGASHI, C.K. et al. Influência de métodos de debicagem e do tipo de bebedouro no desempenho e na qualidade dos ovos de codornas japonesas. Rev. Bras. Zootec., v.40, p.6, 2011.

LILBURN, M.S. Skeletal growth of commercial poultry species. Poult. Sci., v.73, p.897-903, 1994.

MARCHANT-FORDE, R.M.; CHENG, H.W Different effects of infrared and one-half hot blade beak trimming on beak topography and growth. Poult. Sci., v.89, p.2559-2564, 2010.
OKA, C.H.; BUENO, L.G.F.; SOUZA, S.R.L. et al. Performance of commercial laying hen submitted to different debeaking methods. Rev. Bras. Cienc. Avic., v.19, p.4, 2017.

RODRIGUEIRO, R.J.B.; ROSTAGNO, H.S.; ALBINO, L.F.T. et al. Exigência nutricional de lisina para poedeiras leves e semipesadas nos períodos de 1 a 3 e de 4 a 6 semanas de idade. Rev. Bras. Zootec., v.36, p.5, 2007.

SANTOS, F.R.; OLIVEIRA, P.R.; MINAFRA, C.S. et al. Desenvolvimento digestivo e aproveitamento energético em frangos de corte. PUBVET, v.6, p.18, 2012.

SCHREIWEIS, M.A.; ORBAN, J.I.; LEDUR, M.C.; HESTER, P.Y. The use of densitometry to detect differences in bone mineral density and content of live white leghorns fed varying levels of dietary calcium. Poult Sci, v.82, p.1292-1301, 2003.

STRUTHERS, S.; CLASSEN, H.L.; GOMIS, S.; SCHWEAN-LARDNER, K. The effect of beak tissue sloughing and post-treatment beak shape on the productivity of infrared beak-treated layer pullets and hens. Poult Sci, v.98, p.3637-3646, 2019.

VIEIRA FILHO, J.A.; GARCIA, E.A.; OBA, E. et al. Índice produtivo e qualidade de ovos de galinhas poedeiras submetidas a diferentes métodos de debicagem. Pesqui. Agropecu. Bras., v.51, p.759-765, 2016

YAMAUCHI, Y.; YOSHIDA, S.; MATSUYAMA, H.; OBI, T.; TAKASE, K. Morphologically abnormal beaks observed in chickens that were beak-trimmed at young ages. J. Vet. Med. Sci., v.79 p. 1466-1471, 2017.

W-36 commercial layers management guide. Des Moines, IA, USA: Hy-Line, p.1-32, 2016.

ZHOU, H.; DEEB, N.; EVOCK-CLOVER, C.M. et al. Genome-Wide linkage analysis to identify chromosomal regions affecting phenotypic traits in the chicken. 3. Skeletal integrity. Poult Sci., v.86, p.255266, 2007. 